ARAŞTIRMA / RESEARCH

\title{
Pnömoni tanısıyla değerlendirilen çocuk hastaların kardiyolojik
} bulgular1

\section{Cardiological findings of pediatric patients with the diagnosis of pneumonia}

\author{
Soner Sertan Kara ${ }^{1}$, Ufuk Utku Güllü , Ali Fettah ${ }^{3}$
}

${ }^{1}$ Erzurum Bölge Eğitim ve Araştırma Hastanesi, Çocuk Enfeksiyon Hastalıkları Kliniği, ${ }^{2}$ Çocuk Kardiyoloji Kliniği, ${ }^{3}$ Çocuk Hematoloji Kliniği, Erzurum, Turkey

\section{Cukurova Medical Journal 2017;42(4):700-706}

\begin{abstract}
Purpose: Pneumonia is an important health problem. Cardiovascular system is involved variously during course of disease. This study aims to investigate children with community-acquired pneumonia.
\end{abstract}

Material Methods: Children aged one month-16 years were prospectively evaluated about some of their clinical, laboratory, radiological, and echocardiographical findings. Also, children with non-cardiac chronic diseases were compared with children having no chronic disease.

Results: Median age of patients was 32 months. Fortyeight $(76.2 \%)$ patients were hospitalized. One fourth of children had congenital heart disease. Among these, 5 $(31.2 \%)$ had hemodynamically instable cardiac defect, while $11(68.7 \%)$ had hemodynamically insignificant cardiac lesions. Tricuspid insufficiency was present in 14, various degrees of pulmonary hypertension were present in $10(15.9 \%)$ patients. One third reported recurrent pulmonary infections. Eighteen $(28.6 \%)$ patients had noncardiac chronic diseases. Mostly lobar infiltration (49.2\%) was present. One quarter had pulmonary complications, most of which were parapneumonic effusion. Patients with non-cardiac chronic diseases had more prevalent recurrent pulmonary infections, tricuspid insufficiency and pulmonary hypertension, and hospitalization than children having no chronic disease.

Conclusion: Serious cardiac complications can be encountered during course of pneumonia. Presence of an underlying non-cardiac chronic disease increase both recurrence and morbidity of pneumonia.

Key words: Child, community-acquired pneumonia, echocardiography, pulmonary hypertension.
Öz

Amaç: Pnömoniler önemli bir sağlık sorunudur. Hastalığın seyrinde kardiyovasküler sisteme ait değişik düzeyde etkilenmeler görülebilir. Bu çalışmayla toplum kökenli pnömoni tanısı konulan çocuk hastaların değerlendirilmesi amaçlanmıştır.

Gereç ve Yöntem: Bir ay-16 yaş arası çocuklar prospektif olarak değerlendirilmiş, bu hastaların bazı klinik, laboratuvar, radyolojik ve ekokardiyografik bulguları araştırılmıstır. Ayrıca altta yatan kalp-dışı kronik hastalı̆̆ olan hastalarla, olmayanlar karşılaştırılmıştır.

Bulgular: Hastaların ortanca yaşı 32 aydi. Kırksekiz (\%76.2) hasta yatırılarak izlendi. Hastaların yaklașık dörtte birinde konjenital kalp hastalı̆g mevcuttu. Bu hastaların 5'inde (\%31.2) kalpte hemodinamik instabilite oluşturan yapisal defekt varken, 11'inde (\%68.7) hemodinamik önemi olmayan yapisal lezyonlar mevcuttu. Ondört $(\% 22.2)$ hastada triküspit yetmezliği, $10(\% 15.9)$ hastada değişik derecelerde pulmoner hipertansiyon saptand. Hastaların üçte birinde tekrarlayan akciğer enfeksiyonu bildirildi. Onsekiz (\%28.6) hastada kalp-dıșı kronik hastalık mevcuttu. Hastaların akciğer grafilerinde çoğunlukla lober tutulum (\%49.2) gözlendi. Dörtte bir hastada akciğerlerde pnömoniye bağlı komplikasyon gözlenirken, bunların çoğunluğu parapnömonik efüzyondu. Altta yatan kalp-dış1 kronik hastalığ enfeksiyonu geçirme, ekokardiyografide triküspit yetmezliği ve pulmoner hipertansiyon bulunma ve hospitalizasyon oranlarının, kronik hastalığı olmayanlara göre daha yüksek olduğu saptandı.

Sonuç: Pnömoniler önemli kardiyak komplikasyonlara yol açabilmektedir. Altta yatan non-kardiyak bir kronik hastalığın varlığı, pnömoninin hem rekürens riskini hem de morbiditesini artırmaktadır.

Anahtar kelimeler: Çocuk, ekokardiyografi, toplum kökenli pnömoni, pulmoner hipertansiyon. 


\section{GİRİ̧̧}

Akciğerin intersitisyel dokusunun ve alveollerin inflamasyonu sonucu ortaya çıkan pnömonilerde hastaların en sık başvuru şikayetleri öksürük, ateş, göğüs ağrısı ve nefes darlı̆̆ıdır. Bu durum, tüm dünyada özellikle 5 yaşın altındaki çocuklarda önemli bir sağlık sorunudur. Her y1l dünya genelinde yaklaşı 155 milyon çocuk pnömoni geçirirken, 5 yaşın altında 2 milyondan fazla çocuk bu nedenle kaybedilmektedir ${ }^{1}$.

Toplum kökenli pnömoni (TKP), pulmoner parankimin toplumdan kazanılmış etkenlerle akut enfeksiyonudur. Neden olan mikroorganizmalar yaşa ve altta yatan hastalıklara göre değişen TKP'ye en s1k neden olan virüsler respiratuvar sinsisyal virüs (RSV), parainfluenza ve influenza virüsleri iken, en sı görülen bakteriyel etkenler $\mathrm{S}$. pneumoniae ve $\mathrm{H}$. influenza'dır ${ }^{2,3}$.

Enfeksiyonlara karşı duyarlllığ1 hem hastaya ait (küçük yaş, düşük doğum yaşı ve tartısı, malnütrisyon, altta yatan hastalık varlığ1, D-vitamini eksikliği, bazı gen polimorfizmi varyantları), hem de çevresel (anne sütü alamama, düşük sosyoekonomik düzey, kalabalık yaşam koşulları, yetersiz bağışıklama, sağlık hizmetlerine ulaşamama, sigara ve diğer ortam hava kirliliklerine maruziyet) faktörler $\operatorname{artır14} 4,5$.

Hastalığın seyrinde bazı komplikasyonlar karşımıza çıkabilmektedir. Akciğerlere sinırlı (parapnömonik efüzyon, akciğer absesi, gibi) ve sistemik komplikasyonlar görülebildiği gibi santral sinir sistemi, kemik-eklem sistemi gibi farklı vücut bölgeleri de etkilenebilmektedir ${ }^{6}$. Pnömonili hastalarda perikardit, miyokardit ve endokarditin yanı sıra, sol ventrikül fonksiyonlarında azalma, aritmiler, akut koroner sendrom, artmış pulmoner arter basınc1, kardiyovasküler otonomik reflekslerde bozulma ve artmış prokoagülan aktivite gibi kardiyovasküler sisteme ait etkilenmeler de bildirilmiştir ${ }^{6,7}$.

$\mathrm{Bu}$ çalışma ile amaçlanan, çocuk polikliniklerinde TPK tanısı konmuş hastaların tanı anındaki bazı klinik, laboratuvar, radyolojik ve ekokardiyografik (EKO) bulgularının araştırılması ve altta yatan kalpdışı kronik hastalığı olan ve olmayan çocukların birbirleriyle arasındaki farkların incelenmesidir. Buradan çıkacak sonuçla, pnömoninin tanı anında çocuk hastalarda kalp üzerindeki etkisinin gösterilmesi amaçlanmıştır.

\section{GEREÇ VE YÖNTEM}

\section{Çalışma prosedürü}

Çalışmaya, 01 Haziran 2015-31 Mayıs 2016 tarihleri arasinda Erzurum Bölge Eğitim ve Araştırma Hastanesi'nde (EBEAH) TKP tanısı alan 1 ay - 18 yaş arası çocuk hastalar prospektif olarak dahil edildi. Pnömoni tanısı konulan hastaların tedavisi ve yönetimi, Amerikan Enfeksiyon Hastalıkları Cemiyeti (IDSA) önerileri doğrultusunda yapıld ${ }^{8}$. Çalışmaya fizik muayenede müphem bulguları ya da komplikasyon şüphesi olduğu için posteroanterior ve lateral akciğer grafisi çekilen veya hospitalizasyon endikasyonu olan hastalar dahil edildi. Bilinen konjenital kalp hastalığı olan, akciğer grafisinde pnömoni bulgusu olmayan ve yenidoğan ya da erişkin (>18 yaş) yaş grubunda olan olgular çalışmaya dahil edilmedi.

Lokal etik kurul onayı (EBEAH Etik Kurul onay no: 2017-03-20) ve hastaların ebeveynlerinden çalışmaya katılım için onam alındı. Hastaların yaş, cinsiyet, altta yatan kalp ve kalp-dışı kronik bir hastalığı olup olmadığ1 ve varsa tipi, tanı anındaki EKO, akciğer grafisi ve laboratuvar (beyaz küre sayısı [WBC] ve trombosit sayıları, hemoglobin, C-reaktif protein [CRP], eritrosit sedimentasyon hızı [ESH] değerleri) bulguları ve hospitalize edilip edilmediği hem hastane dijital kayıtlarına hem de çalışma formlarına kaydedildi.

Çocuk Enfeksiyon Hastalıkları polikliniğinde pnömoni tanısı konulan hastaların akciğer grafilerine ait özellikler Radyoloji bölümü uzmanlarınca da yorumlandiktan sonra kaydedildi. Tüm hastalara ilk başvuru gününde, tedaviye başlanmadan önce kardiyolojik değerlendirme (fizik inceleme, elektrokardiyografi [EKG] ve EKO) aynı Çocuk Kardiyoloji uzmanı tarafindan yapıldı. Hastaların tamamı Vivid S5 EKO cihazı kullanılarak tetkik edildi. Triküspit geri kaçış hızı, sağ ventrikül dilatasyonu ve morfolojisi değerlendirilerek pulmoner hipertansiyon (PH) varlığ ve derecesi belirlendi. PH'nin non-invaziv olarak tanısında temel tarama testi olan EKO yapıldı. PH tanı kriterleri olarak Avrupa Kardiyoloji Cemiyeti'nin (ESC) belirlediği PH tanı ve tedavi kılavuzu kulllanıldı? Buna göre triküspit gerikaçış hızı ve kardiyak morfoloji baz alındı. Parasternal uzun eksen bakıda yapılan M mod ölçüm ile sağ ventrikül çapı ölçüldü. Bulunan değerin kiloya göre Z skoru bakilarak sağ ventrikül dilatasyonu tanısı konuldu. 
Çalışmada kronik hastalığ1 olup, hemodinamik önemi olan kalp hastalığ1 olmayan hastalar Grup-1, kalp-dışı kronik hastalığı ve hemodinamik önemi olan kalp hastalığ olmayan hastalarsa Grup-2 olarak tanımland. Her iki grup bazı klinik ve ekokardiyografik özellikleri açısından karşılaştırıldı.

\section{İstatistiksel analiz}

Çalışma verilerinin istatistiksel analizi Statistical Package for Social Science (SPSS) 18.0 paket programında yapıldı. Değişkenlerin normal dağılıma uygunluğu Kolmogrov-Smirnov/Shapiro-Wilk testleri ile değerlendirildi. Normal dağılan değişkenler için ortalama \pm standart sapma, normal dağılmayanlar değişkenler için ortanca (minimummaksimum) değerler verildi. Kategorik veriler "\%" olarak gösterildi. Gruplar arasındaki sıklıklar bakımından fark bulunup bulunmadığ $\mathrm{Ki}$-kare testi kullanılarak karşılaştırıldı. p <0.05 istatistiksel olarak anlamlı olarak kabul edildi.

\section{BULGULAR}

Çalışmaya 63 hasta dahil edildi. Hastaların yaşları 1 ay ile 17.6 yaş arasında değişmektediydi ve ortanca yaşı 32 aydı. Erkek çocuklar çoğunluktayd1, kı/ erkek oranı 0.61 idi (Tablo 1). Kırksekiz (\%76.2) hasta yatırilarak tedavi edildi. Sekiz hastanin izleminde yoğun bakım ihtiyacı oldu. Serebral palsi ve ağır pulmoner hipertansiyon (primer?) tanısı olan bir hasta hastaneye yatışının ikinci gününde kaybedildi. Hastaların yaklaşık dörtte birinde konjenital kalp hastalı̆̆1 mevcuttu. Bu hastaların 5'inde (\%31.2) kalpte hemodinamik instabilite oluşturan yapısal defekt varken, 11'inde (\%68.7) hemodinamik önemi olmayan yapisal lezyonlar mevcuttu (küçük atriyal septal defekt [ASD] ve patent foramen ovale [PFO]).

Çalışma sırasında 3 hasta (Birinci hasta kardiyak tip total anormal pulmoner venöz dönüş anomalisi, ikinci hasta inferior kaval tip multipl ASD+parsiyel anormal pulmoner venöz dönüş anomalisi ve üçüncü hasta ağır aort koarktasyonu+ağır mitral yetmezlik +orta mitral stenoz+ince patent duktus arteriozus) kardiyak sorunları nedeniyle opere edildi. Hastaların geneline bakıldığında sol ventrikülde dilatasyon sadece ağır aort koarktasyonu+ağır mitral yetmezlik+orta mitral stenoz+ince patent duktus arteriozus olan hastada [ $\mathrm{n}=1(\% 1.6)]$ görülürken, sağ ventrikül dilatasyonu 7 (\%11.1) hastada gözlendi. EKO'da hastaların 14'ünde (\%22.2) triküspit yetmezliği, 10’unda (\%15.9) değissik derecelerde pulmoner hipertansiyon saptandı (Tablo 2). Hastaların üçte birinde tekrarlayan akciğer enfeksiyonu bildirildi. Kalp hastalıkları dışında, kronik hastalığı bulunan 18 (\%28.6) hasta mevcuttu. Bu hastaların 5’i (\%27) serebral palsi, 3’ü (\%16.6) bronkopulmoner displazi, 3 ’ü (\%16.6) orta-ağır malnütrisyon, 3’ü (\%16.6) bronşial astım, 2'si (\%11.1) kistik fibrozis, 2'si (\%11.1) spinal müsküler atrofi, 1'er (\%5.5) hasta da opere yarık damakdudak, opere meningomyelosel + ventriküloperitoneal şant ve Down sendromu tanilariyla izlenmekteydi.

Tablo 1. Hastaların demografik ve klinik özellikleri

\begin{tabular}{|l|l|}
\hline Özellik & n (\%) \\
\hline Yaş (ay) (ortanca [minimum-maksimum]) & $32[1-212]$ \\
\hline Erkek cinsiyet & $39(61.9)$ \\
\hline Tekrarlayan akciğer enfeksiyonu öyküsü & $21(33.3)$ \\
\hline Altta yatan kalp-dısı kronik hastalık $\beta$ & $18(28.6)$ \\
\hline Konjenital kalp hastalı̆ı $\alpha$ & $16(25.4)$ \\
\hline İnferior kaval tip multipl ASD+PAPVDA & $1(6.2)$ \\
\hline Ağır AK+ağır MY+orta MS+ince PDA & $1(6.2)$ \\
\hline $\begin{array}{l}\text { Total anormal pulmoner venöz dönüş } \\
\text { anomalisi }\end{array}$ & $1(6.2)$ \\
\hline Orta ASD & $2(12.5)$ \\
\hline Hemodinamik önemi olmayan lezyonlar & $11(68.7)$ \\
\hline Hospitalizasyon & $48(76.2)$ \\
\hline
\end{tabular}

$\alpha$, ASD, atrial septal defekt; PAPVDA, parsiyel anormal pulmoner venöz dönüş anomalisi; AK, aort koarktasyonu; $\mathrm{MY}$, mitral yetmezlik; MS, mitral stenoz; PDA, patent duktus arteriozus

Hastaların akciğer grafilerinde çoğunlukla sağ akciğer (\%50.8) ve lober tutulum (\%49.2) gözlendi (Tablo 2). Dörtte bir hastada akciğerlerde pnömoniye bağlı komplikasyon gözlenirken, bunların çoğunluğu parapnömonik efüzyon şeklindeydi. Efüzyonu olan hastalardan 6's1 göğüs tüpü takılarak izlendi. Hastaların hiçbirisinde plevral s1v1 kültürlerinde üreme saptanmadı. Hastalara ait bașvuru anındaki laboratuvar bulguları Tablo 3'te gösterilmiştir. Hastaların beyaz küre ve trombosit sayıları, hemoglobin ve C-reaktif protein değerleri ortalama veya ortanca değerleri normal aralıkta görülmekte iken eritrosit sedimentasyon hiz1 ortalama değeri normal aralığın hafif üstünde saptandı. Çalışmada Grup 1 ve 2'nin karşılaştırılması Tablo 4'te gösterilmiştir. Altta yatan kronik hastalık varlığının, daha yüksek oranlarda tekrarlayan akciğer enfeksiyonu geçirme, EKO'da triküspit yetmezliği ve pulmoner hipertansiyon bulunma ve hospitalizasyon ile ilişkili olduğu saptandı (sırasıyla, $\mathrm{p}<0.0001, \mathrm{p}=0.005, \mathrm{p}=0.001$ ve $\mathrm{p}=0.01)$. 
Tablo 2. Hastaların ekokardiyografik ve radyolojik özellikleri

\begin{tabular}{|l|c|}
\hline Özellik & \multicolumn{2}{|c|}{ n (\%) } \\
\hline Ekokardiyografi bulguları & $1(1.6)$ \\
\hline Sol ventrikülde dilatasyon & $7(11.1)$ \\
\hline Sağ ventrikülde dilatasyon & $14(22.2)$ \\
\hline Triküspit yetmezliği & $10(71.4)$ \\
\hline Hafif & $2(14.2)$ \\
\hline Orta & $2(14.2)$ \\
\hline Ağır & $10(15.9)$ \\
\hline Pulmoner hipertansiyon & $5(50)$ \\
\hline Hafif & $5(50)$ \\
\hline Ağır & \\
\hline Akciğer grafisi bulguları & $32(50.8)$ \\
\hline Akciğer grafisinde pnömonik tutulum bölgesi & $16(25.4)$ \\
\hline Săg akciğer & $15(23.8)$ \\
\hline Sol akciğer & \\
\hline Bilateral & $20(31.7)$ \\
\hline Akciğer grafisinde pnömonik tutulum şekli & $31(49.2)$ \\
\hline Parakardiyak & $12(19)$ \\
\hline Lober & $16(25.4)$ \\
\hline İnterstisyel & $10(62.5)$ \\
\hline Akciğerde komplikasyon & $5(31.2)$ \\
\hline Parapnömonik efüzyon & $1(6.2)$ \\
\hline Atelektazi & \\
\hline Akut respiratuvar distres sendromu & \\
\hline
\end{tabular}

Tablo 3. Hastaların laboratuvar bulguları

\begin{tabular}{|l|c|}
\hline Beyaz küre sayıs $(/ \mathrm{uL})($ ortalama $\pm \mathrm{SD})$ & $12,093 \pm 1897$ \\
\hline Hemoglobin değeri $(\mathrm{gr} / \mathrm{dL})($ ortalama $\pm \mathrm{SD})$ & $12.1 \pm 1.8$ \\
\hline Trombosit sayısı $(/ \mathrm{uL})($ ortalama $\pm \mathrm{SD})$ & $406,900 \pm 168,229$ \\
\hline C-reaktif protein değeri $(0-5 \mathrm{mg} / \mathrm{dL})($ ortanca $[$ min-maks]) & $1.8[0.3-21.0]$ \\
\hline Eritrosit sedimentasyon hız1 $(0-20 \mathrm{~mm} /$ saat) (ortalama $\pm \mathrm{SD})$ & $22.8 \pm 12.7$ \\
\hline
\end{tabular}

SD: standart deviasyon, min: minimum, maks: maksimum

Tablo 4. Altta yatan kalp-dışı kronik hastalık varlığının hastaların bazı klinik ve ekokardiyografik özellikleriyle ilişkisi

\begin{tabular}{|l|l|l|l|}
\hline Parametre & Grup 1 $\mathbf{n = 1 7 ~ ( \% 2 6 . 9 ) ~}$ & Grup 2 $\mathbf{n = 4 1}(\mathbf{0 6 5})$ & p değeri \\
\hline Tekrarlayan akciğer enfeksiyonu & $15(71.4)$ & $6(28.6)$ & $<\mathbf{0 . 0 0 0 1}$ \\
\hline Akciğerde pnömoni komplikasyonu & $5(31.3)$ & $11(68.8)$ & 0.83 \\
\hline Triküspit yetmezliği & $9(64.3)$ & $5(35.7)$ & $\mathbf{0 . 0 0 5 *}$ \\
\hline Pulmoner hipertansiyon & $8(80.0)$ & $2(20.0)$ & $\mathbf{0 . 0 0 1 *}$ \\
\hline Hospitalizasyon & $20(41.7)$ & $28(58.3)$ & $\mathbf{0 . 0 1}$ \\
\hline
\end{tabular}

*, istatistiksel olarak anlamlı; Grup 1: Kronik hastalık var, hemodinamik önemi olan kalp hastalığ1 yok; Grup 2: Kronik hastalık ve hemodinamik önemi olan kalp hastalığı yok

\section{TARTIŞMA}

Bu çalışma ile pnömoni tanısı konulan çocuk hastalar klinik, laboratuvar, radyolojik ve ekokardiyografik özellikleriyle incelendi. Hastaların \%25.4'ünde konjenital kalp hastalığı, \%28.6'sında altta yatan bir kalp-dışı hastalık saptandı. Kronik (kalp-dışı) hastalığ1 olan pnömonili çocukların, tekrarlayan akciğer enfeksiyonu geçirme, EKO'da triküspit yetmezliği ve pulmoner hipertansiyon bulgularınin ve bu ataklarinda hastaneye yatma oranlarının kronik hastalığı olmayan çocuklara göre daha yüksek olduğu bulundu. Hafif şiddette de olsa, pnömoni sırasında mutlaka kalp-damar sisteminde etkilenmeler olabilmektedir. Literatürde pnömoni nedenli hastaneye yatan erişkinlerin dörtte birinde 
hastanede yatış sırasında akut majör bir kardiyak komplikasyonun geliştiği ve bu durumun kısa dönemde mortaliteyi \%60'lara varan oranlarda artırdığ1 bildirilmiştir ${ }^{7}$. Akciğerlerin enfeksiyonu sırasında kalp ve damar sistemi birçok mekanizma ile etkilenebilmektedir. Öncesinde herhangi bir hastalığ1 bulunmasa da, kanda dolaşan inflamatuvar mediatörler (sitokinler, endotoksinler vs) ve kalbin ön ve art yükünü etkileyen vasküler cevap nedeniyle sol ventrikül fonksiyonlarında geçici bir baskılanma olmaktadir ${ }^{10}$. Bu esnada kanda troponinler, Bnatriüretik peptid ve atriyal natriüretik peptid düzeylerinde artış görülmektedir ${ }^{7}$ Bizim çalışmamızda bu belirteçlerin düzeylerine bakılamad1. Pnömoniye de s1k sebep olan bazı mikroorganizmalar (influenza virüs, RSV, adenovirüs, enterovirüsler, Mycoplasma pneumoniae, Chlamydophila pneumoniae, Staphylococcus aureus, pnömokoklar ve Legionella spp) direkt miyokardit yaparak kalp hasarı oluşturmaktadır ${ }^{7}$. En sık pnömoni etkeni olan pnömokokların, miyokart içine invazyonla ya da miyonekroz yapan pnömolizin veya hidrojen peroksit salgılayarak kardiyotoksisite oluşturabildiği gösterilmiştir ${ }^{11}$. Bunların yanı sıra pnömoniler sırasında oluşan hipoksemi ve konsolide akciğer parankimi sonucunda pulmoner ventilasyonperfüzyon bozulur ve pulmoner arter basinc1 $\operatorname{artar}^{12}$. Solunum yolu enfeksiyonu olmas1 durumunda $\mathrm{PH}$ semptom ve fizik bulguları artış gösterebilir. Önceden de var olan PH artabileceği gibi, enfeksiyon döneminde ilk defa PH başlamış olabilir. Bulguların duyarlılığı tartışmalı olsa da, sağ kalp odacıklarının boyutlarının artması, interventriküler septum biçim ve işlev anormallikleri, sağ ventrikül duvar kalınlığında artış ve dilate ana pulmoner arter de PH'yi düşündürür'?. Bizim çalışmamızda da altta yatan konjenital kalp hastalığı olmayan hastalarda sağ ventrikülde dilatasyon, triküspit yetmezliği ve pulmoner hipertansiyon bulgular1 saptand1. Pnömoniler sırasında aritmiler de izlenebilmektedir. Hem enfeksiyonun kendisi, hem de tedavide kullanilan bir makrolid ya da florokinolon grubu antibiyotik, QT uzaması ve ventriküler taşiaritmi gibi aritmiler yapabiliri ${ }^{13}$. Çalışmamızda yer alan hastalarda miyokardit ve aritmiye rastlanmadi.

Çeşitli kronik hastalıkları olan hastalarımızda, lokal veya sistemik olarak immünitenin baskılanmas1, aspirasyon riskinin artması, akciğer alveol ve intersitisyel yapının bozulmuş olması ve mukosiliyer klerensin azalması gibi nedenlerle tekrarlayan akciğer enfeksiyon riskinin arttığı düşünüldü. Pnömoniye bağlı olarak kalp yetmezliği ortaya çıkabileceği gibi, öncesinde kalp yetmezliği bulunması da pnömoni oluşmasını kolaylaştırır. Hâlihazırda mevcut bir kalp hastalığ1 varsa tedavide kullanılan antibiyotiklerin yan-etkileri ve oksijenasyon bozukluğu miyokardiyal talebi arttırabilir ${ }^{11}$. Çalışmamızda konjenital kalp hastalıkları, serebral palsi, bronkopulmoner displazi, malnütrisyon ve bronşial astım en sik saptanan hastalıklardı. Ülkemizde tekrarlayan pnömonisi olup hospitalize edilen çocuk hastalar Solmaz ve arkadaşları tarafindan yapılan çalışmada değerlendirilmiş ve en sık etiyolojik nedenler olarak konjenital kalp hastalığı, gastroözofageal reflü, aspirasyon sendromları (yabanc1 cisim aspirasyonu, serebral palsi ve kas hastalığ1), bronşiyal astım ve kistik fibrozis bulunmuştur ${ }^{14}$. Bizim çalışmamızda kalp-dış1 kronik hastalığ1 olan hastaların hospitalizasyon oranları da daha yüksek saptand. Bu durum, bu hastaların göreceli olarak daha düşük kardiyorespiratuvar kapasiteye sahip olmalarına bağlı oldukları ya da bu pnömoni ataklarını daha ağır geçirdikleri şeklinde yorumlandı.

Pnömoniye yatkınlık, sistemik ya da sekretuvar bağışıklık azaldığında artmaktadır. Tüm dünyada en sık etkilenen yaş grubu duyarlılı̆̆ın en yüksek olduğu dönem olan 5 yaşın altındaki çocuklardır. Bu çalışmada da hastaların yaş ortancası da 32 ay olarak saptandi. Bakteriyel pnömoninin en s1k radyolojik bulgularından olan lober pnömoni, bu çalışmada da hastaların yaklașık yarısında saptanmıştır. Diğer sık infiltrasyon şekilleri, bakteriyel pnömonilerin solunum yolu ve çevre intersitisyumu primer olarak infiltre edebilmesi iken, s1klıkla viral pnömonilerin intersitisyel ve/veya parankimal infiltrasyonudur ${ }^{15}$. Radyografi, 12 ayın altındaki veya tanının kesinleştirilemediği, ya da ağı hastalık bulgusu olan, komplikasyon geliştiği düşünülen ve hospitalize edilen hastalarda çekilmelidir ${ }^{15}$. Bu çalışmada da bu endikasyonlarla grafi çekilen hastalar dahil edildi.

Pnömonilerin laboratuvar tanısında pek çok belirtecin hassasiyet ve özgüllüğü araştırılmıştır. Rutin kullanımda en sik parametreler olan WBC, periferik yayma incelemesi, CRP ve ESH gibi belirteçlerin, çoğu invaziv bakteriyel enfeksiyonda arttı̆̆1 gibi, bakteriyel nedenli toplum kökenli pnömonilerde de artması beklenir. Ancak bunlar tek başlarına enfeksiyon - enfeksiyon dışı nedenlerle, viral - bakteriyel etken ayrımında yeterli değildir ${ }^{16}$. Çalışmada bu belirteçlerin ortalama/ortanca değerlerinin normal aralıkta veya hafif yüksek saptanması, olguların pnömoni etiyolojisinde viral 
etkenlerin rol oynadığını ya da olguların kliniğinden kardiyolojik sorunlar gibi diğer etkenlerin sorumlu olabileceğini düşündürdü. $\mathrm{Bu}$ çalışmada bu belirteçler açısından olgular arasında herhangi bir karşılaştırma yapılmadı.

Parapnömonik efüzyon ve plevral ampiyem TKP'nin en sık komplikasyonlarıdır. Aşılamanın yaygin olduğu ülkelerde bile Streptococcus pneumoniae en sik etiyolojik etkenken onu sirasiyla Streptococcus pyogenes ve Staphylococcus aureus takip etmektedir ${ }^{17}$. Bizim çalışmamızda da en sik gelişen komplikasyon parapnömonik efüzyondur. $\mathrm{Bu}$ hastaların 6's1 antibiyotik tedavisine ilaveten gögüs tüpü ile takip edilmiştir ancak hastaların çoğunluğu hastanemize başvuru öncesinde antibiyotik tedavisi aldığı için plevral sıv1 kültürlerinde üreme saptanmadığı düşünüldü. Dünya genelinde 7- ve 13-valanlı konjüge pnömokok aşılaması sonrası pnömoniye bağlı hastaneye yatışlarda ve mortalitede azalma göstermiştir ${ }^{18}$. Ülkemizde konjüge pnömokok ve Haemophilus influenzae tip B aşısının da içinde bulunduğu beşli karma aşının aşılama hızları son verilerde \%09-97 gibi yüksek oranlarda bildirilmiştir ${ }^{19}$. Bizim çalışmamızda hastaların aşılanma durumu ile ilgili veri bulunmamaktadır ve aşılama durumunu bilmediğimiz bir hastada mortalite izlenmiștir.

Sonuç olarak, birbiriyle yakın ilişkisi olması sebebiyle akciğer enfeksiyonlarında kardiyovasküler sistem de değişik derecelerde etkilenmektedir. Altta yatan nonkardiyak bir kronik hastalığın varlığı, pnömoninin hem rekürens riskini hem de morbiditesini artırmaktadır. Bu durumun önemi iyi bilinmeli ve özellikle risk grubundaki hastalarda pnömoninin önlenmesi ve geliştikten sonra yakın takibi konusunda dikkatli olunmalıdır.

\section{KAYNAKLAR}

1. World Health Organization. Pneumonia. Fact sheet No. 331. 2009. Available from http://www.who.int/mediacentre/factsheets/fs331/ en/index.html (accessed May 2016).

2. Das A, Patgiri SJ, Saikia L, Dowerah P, Nath R. Bacterial pathogens associated with communityacquired pneumonia in children aged below five years. Indian Pediatr. 2016;53:225-7.

3. Michelow IC, Olsen K, Lozano J, Rollins NK, Duffy LB, Ziegler $\mathrm{T}$ et al. Epidemiology and clinical characteristics of community-acquired pneumonia in hospitalized children. Pediatrics. 2004;113:701-7.

4. Kocabaş E, Doğru Ersöz D, Karakoç F, Tanir G,
Cengiz AB, Gür D et al. Türk Toraks Derneği çocuklarda toplumda gelişen pnömoni tanı ve tedavi uzlaşı raporu. Türk Toraks Dergisi. 2009;S3:1-24.

5. Salnikova LE, Smelaya TV, Moroz VV, Golubev AM, Rubanovich AV. Host genetic risk factors for community-acquired pneumonia. Gene. 2013;518:449-56.

6. Lee GE, Lorch SA, Sheffler-Collins S, Kronman MP, Shah SS. National hospitalization trends for pediatric pneumonia and associated complications. Pediatrics. 2010;126:204-13.

7. Corrales-Medina VF, Musher DM, Shachkina S, Chirinos JA. Acute pneumonia and the cardiovascular system. Lancet. 2013;381:496-505.

8. Bradley JS, Byington CL, Shah SS, Alverson B, Carter ER, Harrison $C$ et al. The management of community-acquired pneumonia in infants and children older than 3 months of age: clinical practice guidelines by the Pediatric Infectious Diseases Society and the Infectious Diseases Society of America. Clin Infect Dis. 2011;53:e25-76.

9. Galiè N, Hoeper MM, Humbert M, Torbicki A, Vachiery JL, Barbera JA et al. 2015 ESC/ERS Guidelines for the diagnosis and treatment of pulmonary hypertension: The Joint Task Force for the Diagnosis and Treatment of Pulmonary Hypertension of the European Society of Cardiology (ESC) and the European Respiratory Society (ERS): Endorsed by: Association for European Paediatric and Congenital Cardiology (AEPC), International Society for Heart and Lung Transplantation (ISHLT). Eur Heart J. 2009;30:2493-537.

10. Kumar R, Wallace WA, Ramirez A, Benson H, Abelmann WH. Hemodynamic effects of pneumonia. II. Expansion of plasma volume. J Clin Invest. 1970;49:799-805.

11. Benson H, Akbarian M, Adler LN, Abelmann WH. Hemodynamic effects of pneumonia. I. Normal and hypodynamic responses. J Clin Invest. 1970;49:79198.

12. Brown AO, Millett ER, Quint JK, Orihuela CJ. Cardiotoxicity during invasive pneumococcal disease. Am J Respir Crit Care Med. 2015;191:739-45.

13. Light RB. Pulmonary pathophysiology of pneumococcal pneumonia. Semin Respir Infect. 1999;14:218-26.

14. Ray WA, Murray KT, Hall K, Arbogast PG, Stein CM. Azithromycin and the risk of cardiovascular death. N Engl J Med. 2012;366:1881-90.

15. Çelebi S, Hacımustafaoğlu M, Albayrak Y, Bulur N. Çocuklarda tekrarlayan pnömoni. Çocuk Enf Derg. 2010;4:56-9.

16. Mani CS, Murray DL. Acute pneumonia and its complications. In Principles and Practice of Pediatric Infectious Disease, 4th ed (Eds SS Long, LP Pickering, CG Prober): 235-45. Pennsylvania, Churchill Livingstone, 2012.

17. Nohynek H, Valkeila E, Leinonen M, Eskola J. 
Erythrocyte sedimentation rate, white blood cell count and serum C-reactive protein in assessing etiologic diagnosis of acute lower respiratory infections in children. Pediatr Infect Dis J. 1995;14:484-90.

18. Krenke $\mathrm{K}$, Urbankowska E, Urbankowski $\mathrm{T}$, Lange J, Kulus M. Clinical characteristics of 323 children with parapneumonic pleural effusion and pleural empyema due to community acquired pneumonia. J Infect Chemother. 2016;22:292-7.

19. Griffin MR, Zhu Y, Moore MR, Whitney CG, Grijalva CG. U.S. hospitalizations for pneumonia after a decade of pneumococcal vaccination. $\mathrm{N}$ Engl J Med. 2013;369:155-63. 